\title{
The Analysis of Factors which are Related to the Compliance of Welder Workers in using Workplace Personal Protective Equipment in Pt. Pal Indonesia
}

\author{
Baiq Fathin Ayuı, Abdul Rohim Tualeka2, Yustinus Denny Ardyanto Wahyudionoz \\ Departement of Occupational Health and Safety, Airlangga University, Surabaya Indonesia
}

\begin{abstract}
The compliance of weld workers in the use of personal protective equipment is one of the major factors in the workplace health and safety. It is because the welder workers have a very high risk of accidents and disease. This research was aimed to find out the factors that related to the compliance of weld workers in the use of the personal protective equipment based on the valid Standard Operating System in PT. PAL Indonesia.

The research was a quantitative research with cross sectional approach. This research used observation method by observing the use of personal protective equipment during the welding process. The variables used in this research were the characteristics of the workers (age, working period, working status, education, and knowledge), responsibility, legitimacy of authority figure, Status of authority figure, supervision, support of coworkers, location status, facilities of personal protective equipment, and standard operating system. The subjects of the research were 72 weld workers. Data were collected by observing directly using check list table cased on the standard operating system that used in PT. PAL Indonesia.

The results showed that knowledge and supervision were the determining factors with p-value 0,003 and 0,014 , it means that workers with little knowledge and without supervision tend to violate the rule to use the personal protective equipment than the ones with knowledge and supervision.
\end{abstract}

Keywords: personal protective equipment, compliance, welder workers

\section{INTRODUCTON}

Ship manufacturing is one of industries which use advanced technology and have high potential of accident. The potential accidents that might happen at ship manufacturing are varied and can be classified as biological, physical, chemical, ergonomic, psychosocial, mechanical, electrical, and $\mathrm{B} 31$ hazards. It is right to say that the work of ship manufacturing has a very high risk of accident. In the period of January 2000 - January 2011, 117 workers died at shipyard in Turkey because of accident at work 1 . The accident in Turkey is caused by five reasons, which are falling from high place, contact with electric or fire, downtrodden and wedged. The result analysis of the cause of accident in Shipyard in Turkey is $80 \%$ caused by unsafe action 2 . One of the works that have high risk of accident and disease is welding process. Welding is an activity done by welder to combine or connect metal. Welding is a work that uses heat. Potential hazards at welding process are; 1). Physical hazards: electric, radiation, heat, fire, wildfire, explosion, noise and magnetic field.; 2) Chemical: welding smoke, fuel gas, inert gas, gas mix and solvent.;

3) General hazard: The hazard do not directly related with welding or metal cutting.

Trauma cases caused by works were 2175 , male workers were placed first with 2112 workers $(97.1 \%)$, and therefore work with the most cases of accidents was welding with 838 cases 4 . Occupational Safety and Health Administration (OSHA) has researched and stated that there are 200 cases of death which are related to welding process generally caused by clumsiness, mistakes in the use of personal protective equipment (PPE), the use of bad personal protective equipment (PPE) and other mistakes5. 
Protective equipment is a control which is obligatory for workers and provided by company. The obligation in using the protective equipment is ruled in the constitution law No.1 year 1970 about work safety6. Even though personal protective equipment is the most simple safety kit, there are still many failure factors in the use of it. The use of protective equipment will be effective if it is used according to the Standard Operating System (SOP). Therefore standard procedure of protective equipments for welder at PT PAL are safety helmet, safety shoes, wear pack, leather apron, stiwel, Welding Helmet, welding respirator, hand shields, long leather gloves7.

The purpose of this research is to know the compliance in using personal protective equipment according to the Standard Operating System (SOP)

\section{MATERIAL AND METHOD}

The type of this research was observational with cross sectional approach. The research location was in PT. PAL Indonesia in trade ship division. The early data was taken in 30 November 2016 and research was done in March 2017. The population was 87 workers which are permanent workers and contemporary workers in the trade ship division of PT. PAL Indonesia. The sample of the research was 72 workers. The data was taken by giving questioner about internal factors (age, working period, employment status, education, knowledge and responsibility) then organization factors (Legitimacy of authority figure, status of authority figure, co-workers support, location status, supervision, facility of personal protective equipment and SOP) and observing the use of personal protective equipment based on the Standard Operating System in PT. PAL Indonesia. The researcher then analyzed the result of the questioner and observation with $\mathrm{ABC}$ theory

\section{FINDING}

Research internal factors in this research can be described in the table 1 below:

Table 1. Internal Factor

\begin{tabular}{|l|l|l|l|}
\hline Variable & Category & Amount & $(\%)$ \\
\hline \multirow{3}{*}{ Age } & 20-30years old & 21 & 29.2 \\
\cline { 2 - 4 } & $31-40$ years old & 17 & 23.6 \\
\cline { 2 - 4 } & $>40$ years old & 34 & 47.2 \\
\hline
\end{tabular}

Cont... Table 1. Internal Factor

\begin{tabular}{|l|l|l|l|}
\hline \multirow{4}{*}{ Working period } & $<5$ years & 26 & 36.1 \\
\cline { 2 - 4 } & $5-10$ years & 8 & 11.1 \\
\cline { 2 - 4 } & $>10$ years & 38 & 52.8 \\
\hline \multirow{4}{*}{$\begin{array}{l}\text { Employment } \\
\text { status }\end{array}$} & Organic & 39 & 54.2 \\
\cline { 2 - 4 } & PKWT & 33 & 48.8 \\
\hline \multirow{5}{*}{ Kducation } & Middle School & 3 & 4.2 \\
\cline { 2 - 4 } & High School & 66 & 91.7 \\
\cline { 2 - 4 } & Undergraduate & 3 & 4.2 \\
\hline \multirow{5}{*}{ Knowledge } & Low & 9 & 12.5 \\
\cline { 2 - 4 } & Enough & 33 & 45.8 \\
\cline { 2 - 4 } & Good & 30 & 41.7 \\
\hline
\end{tabular}

Characteristic data collection was done by questioner covered age, working period, employment status, education and knowledge.

The result of external factors questioner which covered responsibility, Legitimacy of authority figure, status of authority figure, co-workers support, location status, supervision, facility of personal protective equipment, standard operating system

Table 2: External Factors

\begin{tabular}{|l|l|l|l|}
\hline Variable & Category & Amount & $\begin{array}{l}\text { Percentage } \\
(\boldsymbol{\%})\end{array}$ \\
\hline \multirow{4}{*}{ Responsibility } & Enough & 6 & 8.3 \\
\cline { 2 - 4 } $\begin{array}{l}\text { authority figure } \\
\text { Gegimacy of }\end{array}$ & Low & 66 & 91.7 \\
\cline { 2 - 4 } Status of authority & Enough & 23 & 2.8 \\
\cline { 2 - 4 } figure & Good & 47 & 61.9 \\
\hline \multirow{4}{*}{ Co-workers support } & Low & 0 & 65.3 \\
\cline { 2 - 4 } & Enough & 34 & 47.2 \\
\cline { 2 - 4 } & Good & 38 & 52.8 \\
\cline { 2 - 4 } & Eow & 5 & 6.9 \\
\hline \multirow{4}{*}{ Location Status } & Good & 29 & 52.8 \\
\hline \multirow{3}{*}{ Supervision } & Low & 2 & 40.3 \\
\cline { 2 - 4 } & Enough & 11 & 2.8 \\
\cline { 2 - 4 } & Good & 59 & 81.9 \\
\hline & Low & 12 & 16.7 \\
\cline { 2 - 4 } & Enough & 35 & 48.6 \\
\cline { 2 - 4 } & Good & 25 & 34.7 \\
\hline
\end{tabular}


Cont... Table 2: External Factors

\begin{tabular}{|l|l|l|l|}
\hline \multirow{2}{*}{$\begin{array}{l}\text { Facility of } \\
\text { protective } \\
\text { equipment }\end{array}$} & Low & 3 & 4.2 \\
\cline { 2 - 4 } & Enough & 19 & 26.4 \\
\cline { 2 - 4 } & Good & 50 & 69.4 \\
\hline \multirow{3}{*}{$\begin{array}{l}\text { Standard Operating } \\
\text { System }\end{array}$} & Low & 3 & 4.2 \\
\cline { 2 - 4 } & Enough & 10 & 13.9 \\
\cline { 2 - 4 } & Good & 59 & 81.9 \\
\hline
\end{tabular}

Observation result on the compliance in using protective equipment according to SOP

Table 3: The compliance in using personal protective equipment according to SOP

\begin{tabular}{|l|l|l|l|}
\hline Variable & Category & Amount & $\begin{array}{l}\text { Percentage } \\
(\%)\end{array}$ \\
\hline $\begin{array}{l}\text { The compliance in } \\
\text { using protective } \\
\text { equipment } \\
\text { according to SOP }\end{array}$ & Low & 6 & 8.3 \\
\cline { 2 - 4 } & Enough & 50 & 69.4 \\
\cline { 2 - 4 } & Good & 16 & 22.2 \\
\hline
\end{tabular}

Spearman Rank correlation test was used to find how far the correlation of internal and external factor to the compliance in the using of personal protective equipment according to the SOP.

Table 4: Results on the correlation of internal and external factor to the compliance in the using of personal protective equipment according to the SOP.

\begin{tabular}{|l|l|l|}
\hline Variables & p- value & Result \\
\hline Age & 0,196 & Insignificant \\
\hline Working Period & 0,496 & Insignificant \\
\hline Employment Status & 0,324 & Insignificant \\
\hline Education & 0,112 & Insignificant \\
\hline Knowledge & 0,022 & Significant \\
\hline Responsibility & 0,082 & Insignificant \\
\hline $\begin{array}{l}\text { Legitimacy of authority } \\
\text { figure }\end{array}$ & 0,296 & Insignificant \\
\hline Status of authority & 0,361 & Insignificant \\
Figure & 0,256 & Insignificant \\
\hline Co-workers support & 0,505 & Insignificant \\
\hline Location Status & 0,039 & Significant \\
\hline Supervision & 0,538 & Insignificant \\
\hline $\begin{array}{l}\text { Facility of protective } \\
\text { Equipment }\end{array}$ & 0,525 & Insignificant \\
\hline SOP & & \\
\hline$(\alpha=0,05)$ & & \\
\hline
\end{tabular}

Table 4 showed the significant correlation between knowledge and supervision of the compliance in the using of personal protective equipment according to SOP.

Tabel 5: Results on regresi ordinal of Knowledge factor and Supervision to the compliance in the using of personal protective equipment according to the SOP.

\begin{tabular}{|l|l|l|l|}
\hline Variable & $\begin{array}{l}\text { Parameter Value } \\
(\mathbf{B})\end{array}$ & P Value & Exp (B) \\
\hline Knowledge & $-2,105$ & 0,003 & 0,12 \\
\hline Supervision & $-1,600$ & 0,014 & 0,2 \\
\hline
\end{tabular}

Table 5 showed the influence correlation between knowledge and supervision of the compliance in the using of personal protective equipment according to SOP.

Age

There was no correlation between age with compliance in using the personal protective equipment according to SOP The result of the researcher showed that workers in the range of age 31-40 have good compliance in the using of personal protective equipment according to the SOP. This statement supported by the result of research done by Diah (2014)8 which stated that there is no significant correlation between age and compliance in using the personal protective equipment.

\section{Working Period}

There was no correlation Working Period with compliance in using the personal protective equipment according to SOP. This statement was supported by research by Yuliana (2016) 9 in which nurses with working period more than 10 years are nurses who have enough compliance in using personal protective equipment. According to (Robbins, 2008) 10 working period that is too long without variation will decrease someone's working spirit to be complied during work.

\section{Employment Status}

There was no correlation Employment Status with compliance in using the personal protective equipment according to SOP. It is supported by a research by Nugroho (2004)11 which stated that there is no correlation between Civil Servants with contract employee in the 
use of personal protective equipment.

\section{Education}

There was no correlation Education with compliance in using the personal protective equipment according to SOP. The results of this study is supported by Anjari (2014) 12 which says there is no relationship between the level of education of workers with compliance with the use of PPE

\section{Knowledge}

The results of this research showed that there is significant correlation between knowledge with compliance in using the personal protective equipment according to SOP and it matched with the research that was done by Anjari (2014) 12 that there are correlation between knowledge with in using the personal protective equipment in construction workers. The other suitable theory is safety triad by Geller (2001) 14 it is explained that knowledge has significant correlation with compliance in using the personal protective equipment.

\section{Responsibility}

From the correlation test, it was found that there was no significant correlation between responsibility with compliance in using the personal personal protective equipment according to SOP. The result of this research is supported by the result of another research conducted by Dewi (2016) 14 which showed that there was no correlation between responsibility with compliance of nurse to wash their hands with handrub.

\section{Legitimacy of authority figure}

There was no correlation between legitimacy of authority figure with compliance in using the personal protective equipment according to SOP. It is supported by the research that was done by (Mahfudhoh, 2015) 15 which stated that the authority level of the management of Jemursari Hospital in Surabaya which based on main task and function, did not influence the compliance in writing formularium prescription.

\section{Status of authority figure}

There was no significant correlation between status of authority figure with the compliance in using the protective equipment according to SOP. It fit the result of a research by Madfudhoh (2015)15 which stated that doctor's perception to the status of authority figure did not influence significantly to the compliance in writing prescription based on formularium.

\section{Co-Workers support}

From the result of the research it was found that there is no correlation between co-workers with the compliance in using the protective equipment according to SOP. It was supported by the research by Miftahul (2013)16 which stated that good co-workers support has decreased compliance in nursery documentation. Social validation by Tyler(2009) ${ }_{17}$ stated that someone take action which recommended by other people or organization only if there is proof that other people have done it before.

\section{Location status}

It was found that there was no correlation between location status with compliance in using the personal protective equipment according to SOP. Meanwhile the result of this research is supported Madfudhoh (2015) 15 that there was no significant correlation between location status with compliance in writing prescription according to formulary.

\section{Supervision}

In this research there was correlation between supervision with compliance in using the personal protective equipment according to SOP. It is compatible with the Milgram theory. One of the certain factors in the research theory of Milgram (1974) 19 is about compliance is supervision or direct presence. The presence of leader can control and give direct guidance about what should be done. The result of this research was also supported by the result of research by Chandra (2015) 20 that there was correlation between supervision with compliance in using the personal protective equipment for ear in PLTD Ampenan.

\section{Facility}

The results found that there was no correlation between the facility of protective equipment with the compliance in using the protective equipment according to SOP. It was supported by the research by Renganis (2012) 21 that even a company has provided free protective equipment, it did not necessarily make the workers realize the importance of personal protective equipment during work. 


\section{SOP}

The result showed that there was no correlation between SOP with the compliance in using the personal protective equipment according the SOP. The result of this research was supported by the research by Anam (2016) 22 which stated that there is no significant correlation between SOP with compliance to obey SOP.

\section{Regresi Ordinal}

Based on ordinal regression test results obtained a significant influence between supervision and knowledge in the use of personal protective equipment in accordance with SOP

\section{CONCLUSION}

The behavior of using protective equipment in PT.PAL Indonesia has enough compliance, there are still many workers did not use complete protective equipment.

There is correlation and influence between knowledge and supervision to the compliance in using protective equipment in PT.PAL Indonesia.

\section{Conflict of Interest: None}

Source of Funding: Departement of Occupational Health and Safety, Airlangga University, Surabaya Indonesia

Ethical Clearance: The study was approved by the institutional Ethical Board of the Public Health, Airlangga University.

All subjects were fully informed about the procedures and objectives of this study and each subject prior to the study signed an informed consent form.

\section{REFERENCES}

1. Barlas, Baris, (2013). Occupational Fatalities in Shipyards : an Analysis in Turkey, Istambul technical University

2. Yilmas ahmed, (2014). Analysis of Shipyard Accident in Turkey, British Journal of Applied Science \& Technology, Vol 5. No. 5, p. 472-481

3. Singh, K. (2013). Safety Considerations In A Welding Process: A Review. International Journal Of Innovative Research In Science, Engineering
And Technology, Vol. 2, No. 2, p 341-250

4. Lombardi D, Pannala, R, Sorock, GS. (2005). Welding Relate Occupational Injuries: A Narrative Analysis, Occupational Environ Med, Vol. 11, p 174-179.

5. Arikunto, (2005). Manajement of Research.

Jakarta: Rineka Cipta.

6. Indonesian law No.1 year 1970 work safety.

7. PT.PAL. (2017). Standart Operating of Personal Protective Equipment , Surabaya : PT.PAL Indonesia (Persero)

8. Diah Kartika, (2014). The Analysis Of Factors Which Related To The Compliance Of Using Workplace Personal Protective Equipment, The Indonesian Journal of Occupational Safety, Health and Environment, Vol. 1, No. 1, Jan-April 2014 : 24-36

9. Yuliana Lina. (2016). The Analysis Of Factor Which Related To Compliance of Using Workplace Personal Protective Equipment (PPE). Thesis. Faculty of Public Health University of Universitas Airlangga. Program Study Occupational Health and Safety.

10. Robbins, Stephen P, (2008) Organizational Behaviour. Jakarta : Salemba Empat.

11. Nugroho, M (2004) The Analysis Of Factors Which Related To Nursing Work of the Regional Officers at Puskesmas Kabupaten Kudus. Thesis. Faculty of Public Health

12. Anjari Ika. (2014). The Related Factors In Compliance of Personal Protective Equipment Application To Bulding Framerwork Labour. The Indonesian Journal of Occupational Safety, Health and Environment, Vol. 1, No. 1, Jan-April 2014 : 120-131

13. Dewi Ningsih, (2016). The Analysis Of Factor Which Related To Compliance of Nurse Handrub when instalating, Thesis. Master Program of Airlangga University. Program Study Occupational Health and Safety.

14. Geller, E Scoot. (2001). The Psychology Of Safety Handbook. New York: Lewis Publisher. 
15. Mahfudhoh Siti, (2015) The Related Factors In Compliance of Prescription corresponding to formulary. Journal of Indonesian Health Administration, Vol. 3, No. 1, Januari-Juni 2015

16. Miftahul, Muh (2013).The Analysis Of Factor Which Related To Nursing care documentation base on Milgram Theory of obedience. Journal of Indonesian Health Administration. Vol.1. No. 1, Maret 2013, Hal 253-262

17. Tyler, Mark B., Luc Zandvliet and Mitra Forouhar (2009). Due Diligence for Human Right : A Risk Based Approach. Corporate Social Responsibility Initiative Working Paper No. 53. Chambridge, MA : John F. Kennedy School of Governmental Information

18. Milgram, S. (1974). Obediance to Authority on Experimental View, NewYork : Tavistock.
19. Chandra Ahmad. (2015). Correlation of Activator and Consequence with compliance behavior in application ears Personal Protective Equipment to diesel power plant in ampenan by PT.PLN Lombok, Skripsi. Faculty of Public Health. University Of Airlangga Surabaya.

20. Rengganis, (2007). Managing The Risk Of Organizational Accident. Ashgade : publishing Ltd. Aldershot Hants.

21. Anam, Khairul, (2016). The Determinant of Complience in Procedur Operational Standart Operating Procedure on Admission of Rubbers PT.Sampit Internasional Banjarmasin on year 2015. Journal of business communication, Vol. 3, No. 5, Januari 2016, hal 132-149 